\title{
ORIENTAÇÃO EDUCACIONAL: O DIÁLOGO FAZ A DIFERENÇA
}

\section{ARTIGO ORIGINAL}

ROCHA, Antônio Carlos da ${ }^{1}$

ROCHA, Antônio Carlos da. Orientação Educacional: 0 diálogo faz a diferença. Revista Científica Multidisciplinar Núcleo do Conhecimento. Ano 05, Ed. 10, Vol. 14, pp. 144-172. Outubro de 2020. ISSN: 2448-0959, Link de acesso: https://www.nucleodoconhecimento.com.br/educacao/o-dialogo

\section{RESUMO}

O presente Artigo conta com um estudo bibliográfico, somado a uma pesquisa quantitativa, além de intervenção interna e externa organizadas pelo Orientador Educacional na Escola Municipal de Ensino Fundamental Fernando de Azevedo no Município Estância Turística de Ouro Preto do Oeste - RO, ano 2019. Trata-se de um diagnóstico e intervenção feitos a partir dos desafios mais comuns que a escola enfrenta bem como a busca por alternativas viáveis para ajudar no desempenho dos alunos e no trabalho dos professores. A experiência contou com um projeto de pesquisa envolvendo teoria e prática, tendo como perspectiva final, a realização do artigo. Com o êxito no projeto, a motivação em escrever o artigo foi maior e, por essa razão, o esforço em compartilhar a experiência com os leitores. Trata-se de uma proposta útil para alunos leitores em formação no curso de pedagogia e áreas afins, a Orientadores Educacionais, mas também a toda a Equipe Gestora das escolas que pensam em um projeto inovador para a Orientação Educacional.

Palavras-Chave: Desafio, diagnóstico, intervenção.

${ }^{1}$ Mestre em Ciências da Educação. Especialização em Ciências da Educação. Especialização em Filosofia da Educação. Especialização em Didática e Metodologia do Ensino Superior. Licenciatura Plena em Pedagogia e Técnico em Agropecuária. 


\section{INTRODUÇÃO}

Pensar em uma educação de qualidade, muitos dizem, é pensar o futuro da nação. Por essa razão, iniciou-se um grande esforço do orientador educacional, contando com a parceria da equipe gestora e professores para ajudar a Escola Municipal de Ensino Fundamental Fernando de Azevedo, a refletir e a diagnosticar, os desafios mais comuns no seu cotidiano escolar. Um Orientador Educacional não deve se isentar dos desafios na escola, pois ao assumir a responsabilidade na função, é seu dever propor o diálogo, e, a partir deste, produzir alternativas que possam ser úteis para o futuro do ambiente escolar. É preciso um diagnóstico da escola e com as descobertas, produzir informações acerca das experiências pesquisadas.

A educação é responsabilidade de toda a sociedade e por essa razão a escola deve mostrar que ela é parte importante do processo, e que, um bom trabalho do profissional depende de uma boa conduta da comunidade local. Se houver sintonia entre escola e comunidade, haverá conquistas em ambos os casos. Os problemas sociais são uma veracidade, principalmente no mundo globalizado em ascensão, mas isso não justifica a ausência de empenho, pois muitos problemas podem ser evitados com ações preventiva. A comunidade local deve estar em sintonia com a escola, e esta, com a comunidade.

Na era moderna, onde, geralmente pai e mãe trabalham fora de casa é notório que o contato da família com os filhos, se restringe muito. Se a família se envolve muito nas redes sociais, esse tempo de contato fica mais escasso. Neste caso, cabe à escola ajudar com esclarecimentos que são perceptíveis por muitas famílias, mas ainda passam despercebidos por alguns familiares. A preocupação está em que muitas famílias estão perdendo o contato com os filhos, deixam de fazerem a sua parte e cobra da escola que os façam. O professor tem o desgaste natural, passa boa parte do seu tempo de sala de aula fazendo a função de educar, que caberia à família, para depois fazer o seu trabalho que é bastante complexo numa era exigente e pragmática como na atualidade. 
Pensando assim, o projeto nasceu para fomentar esse diálogo com a equipe, a família e a comunidade escolar. Ele visou diagnosticar os desafios mais comuns que os alunos enfrentam e propor alternativas à comunidade local, área de abrangência da escola. Buscou-se ampliar o ângulo de visão para que ambos, a escola e a comunidade fossem beneficiadas. Não se trata de soluções mágicas para sanar os problemas da escola e da comunidade, até porque eles são diversos e não serão extintos na sua totalidade nesse momento, mas trata-se de um diagnóstico sobre os possíveis desafios, considerados os mais comuns, e, a busca por alternativas, para que a escola pudesse conquistar avanços mais consistentes e um futuro promissor.

O artigo é fruto dessa pesquisa e está organizado em três capítulos para melhor detalhar a intencionalidade do que se propôs no planejamento do projeto. No primeiro capítulo do artigo aparecem informações básicas sobre a estruturação do o projeto de pesquisa. Por sua vez, o segundo capítulo traz o referencial teórico estudado. E, o último capítulo vem descrever a parte prática da experiência envolvendo os diálogos, o levantamento de dados da pesquisa, gráficos, as intervenções, tendo como ponto culminante, a palestra e a apresentação de teatro.

Portanto, essa pesquisa quantitativa de procedimentos estruturados e instrumentos de coletas de dados em caráter fechado, tem suas análises de dados numéricos apresentadas em elementos gráficos ao final do artigo. Espera-se que o leitor possa usufruir da experiência e ampliar o debate em torno dessa demanda que é frequente nas escolas. $O$ artigo é importante para atender aos estudantes em Pedagogia e áreas afins, serve como suporte ao Orientador Educacional, mas também, à equipe gestora das escolas que queiram desenvolver projetos nesta perspectiva.

\section{A BASE ESTRUTURAL DO PROJETO}

O grande desafio enfrentado pelas escolas nos últimos tempos tem uma relação muito forte com a questão disciplinar. As famílias modernas vêm ganhado novas dimensões estruturais, situação essa, que muitas vezes impõem sobre seus filhos novos comportamentos que fogem a "normalidade" tradicional. Tanto a família, os alunos e a sociedade estão sentindo dificuldades em aceitar, ou, se adaptar, a tais mudanças, 
exigências do mundo globalizado e mudanças constantes. Considerando o cognitivo, a complexidade aumenta. Com base nesse foco primordial é que nasce o problema para a pesquisa.

Utilizou-se como Título do projeto a seguinte expressão: "Há Uma Luz No Fundo do Túnel: "A rebeldia pode ser um pedido de socorro"”. O título apareceu como pressuposto para despertar a comunidade e os estudantes sobre a perspectiva que se tem quando há o diálogo em busca de mudanças. Ficou evidente que havendo o diálogo, também se encontra respostas para sanar dificuldades que parecem estar sem solução. É nesta perspectiva do diálogo que aconteceu a aposta nos alunos e na comunidade para melhor Ihes servirem.

O problema nasce da seguinte situação: "A Escola Fernando de Azevedo, como tantas outras escolas do país, enfrenta desafios diários para sanar os problemas do ensinoaprendizagem e indisciplina: Que desafios são mais frequentes? Onde há necessidade de ações preventivas para a ajudar escola e a comunidade? Como produzir alternativas para amenizar, ou até mesmo, solucionar tais desafios?". Como em todo projeto, as interrogações nos ajudaram na definição do Objetivo Geral, neste caso, ficou definido que iríamos: "Investigar os desafios mais comuns que Escola Municipal de Ensino Fundamental Fernando de Azevedo no Município - Estância Turística de Ouro Preto do Oeste - RO enfrentava ano 2019 para desenvolver o trabalho no ensino/aprendizagem dos alunos e propor possíveis alternativas que estimulem avanços consistentes à escola e à comunidade".

Nos Objetivos Específicos visou-se as seguintes possibilidades: - Mapear os desafios mais comuns no cotidiano escolar; - Identificar a possíveis causas das dificuldades que 0 aluno enfrenta a partir de uma sondagem acerca destas circunstâncias; Entrevistar pais e alunos que estivessem envolvidos em situações adversas; - Propor medidas que sirvam como alternativas para que a escola e comunidade pensarem juntas novas projeções; - Produzir um artigo científico como registro da experiência, ao final do projeto. 
Assim sendo, prosseguiu-se com a justificativa, pontuando que: A Escola Municipal de Ensino Fundamental Fernando de Azevedo está localizada no Município Estância Turística de Ouro Preto do Oeste, Região Central do Estado de Rondônia. Trata-se de uma escola que está localizada em uma das áreas carentes da cidade, tanto financeira, estrutural e consequentemente, uma acentuada carência afetiva. Portanto, um dos esclarecimentos iniciais que justificou o projeto foi a situação da carência, em geral, como uma das bases da preocupação. Por essa razão, buscou-se entender e contribuir para identificar possíveis desafios que a escola precisaria enfrentar para contribuir com a comunidade de forma extra ao conteúdo proposto.

Pois, ao chegar na escola e passar a compor a sua equipe gestora com a Orientação Educacional, vivenciar situações pertinentes a conduta dos alunos e familiares, o Orientador Educacional sentiu-se na responsabilidade de contribuir com a escola e ir além do espaço fechado em uma sala da orientação, e, por essa razão, percebeu-se que seria necessário investigar e entender os diversos desafios que a escola enfrentava para se sentir apto a oferecer subsídios mais relevantes. Na menor das hipóteses, sugerir ideias a serem debatidas na escola envolvendo o aluno e a família.

Para essa proposta acontecer, acreditou-se ser preciso ir além da investigação, seria necessário envolver as opiniões dos alunos, dos pais e dos profissionais da escola. Se há carência na comunidade, certamente necessitar fazer o diagnóstico de forma mais precisa para que possa tratar da situação real da escola e comunidade em um viés mais seguro. Viu-se, a partir do diagnóstico ser possível propor novos desafios aos alunos e familiares. Seria necessário investigar a própria realidade, pois somente assim haveria como propor uma alternativa equivalente às ações necessárias a serem debatidas, dentre elas: pensou-se num levantamento de dados; palestras; debates, e, se possível, um seminário ao final do semestre.

Por último, houve o comprometimento do próprio Orientador em escrever um artigo científico, como complemento à pesquisa, enviá-lo a uma revista para a publicação, daí o nascimento deste artigo. Assim sendo, justificou-se a necessidade do projeto que seria desenvolvido no decorrer do $2^{\circ}$ semestre do ano de 2019 . Nesta perspectiva fez-se o trabalho ajudando na demanda da escola e comunidade para influenciar na 
melhoria das distintas situações: da família a sua estrutura e destas aos problemas sociais e emocionais, comuns em regiões com esse perfil. Finaliza-se a justificativa demonstrando a esperança de que a soma da força que tem a comunidade aos conselhos da escola, a partir do projeto, ambas, seriam ajudadas no dia a dia de trabalho.

Quanto à metodologia da pesquisa, definiu-se que haveria estudo de referenciais bibliográficos pertinentes à demanda do projeto, além de questionários fechados, pois se pensou na pesquisa quantitativa, estruturada, e, se necessário, entrevistas, considerando que o projeto envolveria alunos, familiares, professores e equipe gestora da escola. Por fim, seria feito a análise da coleta dos dados e a apresentação gráfica que você poderá ver em anexo no final do artigo.

As ações do projeto foram definidas a partir de um cronograma. Portanto, usou-se um levantamento de dados na fase inicial com o nome de 10 alunos do período matutino e 10 alunos do período vespertino em situação disciplinar indesejada. Foi considerado a sugestão dos professores, mas também, registros na sala do Serviço de Orientação Educacional - SOE. Depois de feito o levantamento, os alunos foram convidados pelo orientador, informados sobre a intenção e o objetivo do projeto. Destaca-se aí, a primeira grande surpresa para o Orientador: trata-se da aceitação unânime dos alunos e o desejo em participar do projeto.

Posteriormente, reuniu-se a turma convidada para a apresentação da proposta inicial e no momento oportuno foi feito um pedido para que houvesse mudança de postura por parte dos interessados. Portanto, a partir daquele momento, esclareceu-se mais detalhes referente ao cronograma que estava organizado envolvendo dadas, momentos específicos das intervenções, datas para se fazer o levantamento de dados e uma previsão de data para a intervenção externa. Havia a previsão de uma palestra para os pais e um seminário final, além do artigo que já foi mencionado, sendo que a palestra com os pais, não foi possível ser realizada. 


\section{REFERENCIAL TEÓRICO}

A humanidade vive um tempo que exige desafios constantes e isso não é novidade até para um leigo. $O$ fato, é que, em meio a tantas informações, aparecem um enorme contingente de crianças e adolescentes que vivem situações adversas. Quando se busca equiparar o "padrão de normalidade" exigido pelo sistema, à realidade em que a pesquisa foi desenvolvida, a preocupação se torna alarmante. É possível perceber um índice elevado de dificuldade, comparando-a, aos padrões das exigências para o futuro da educação brasileira. Acredita-se, obviamente, que é uma realidade não diferente de tantas outras escolas de regiões carentes no país.

A preocupação que instigou fazer o trabalho foi também a que impulsionou a mapear os desafios mais comuns no cotidiano da escola e, posteriormente, a identificar as causas destes problemas. Visto isso, decidiu-se entrevistar as pessoas envolvidas no ambiente escolar, sendo eles: os profissionais da educação e os alunos. Buscou-se, propor medidas alternativas que instigasse a escola e a comunidade a fazerem novas projeções para o futuro. Além da parte motivacional que é primordial neste ambiente, persistimos no compromisso e a elaboração do artigo que seria enviado para publicação e divulgação do nosso projeto.

...planejamento é uma ação reflexiva, viva, contínua. Uma atividade constante, permeada por um processo de avaliação e revisão sobre o que somos, fazemos e precisamos realizar para atingir nossos objetivos. E um ato decisório, portanto, político, pois nos exige escolhas, opções metodológicas e teóricas. Também é ético, uma vez que põe em questão ideias, valores, crenças e projetos que alimentam nossa prática. (FARIAS et. al., 2011, p. 111).

Pensando nesta perspectiva, as ideias foram sendo construídas com a elaboração do projeto, um planejamento pensado para o segundo semestre, tendo como intuito proporcionar reflexão, tanto para os alunos envolvidos na experiência, quanto para a escola que é a promotora de todo o processo educativo. Por escola se entende os envolvidos no trabalho diário, da equipe gestora aos distintos funcionários que contribuem para o bom andamento dela. Portanto, buscamos envolver teoria e prática 
num anseio de ser útil às projeções futuras, contamos com uma possível avaliação do nível de contribuição que o trabalho iria permitir construir.

...A avaliação, portanto, permeia todos os momentos do planejamento na fase anterior à sistematização dos planos (avaliação diagnóstica), durante sua execução (avaliação formativa ou de processo) e ao término do trabalho realizado (avaliação do resultado). Somente ela apresentará as informações necessárias ao planejamento e replanejamento da nossa prática, sem precisarmos começar da estaca zero. (FARIAS et. al., 2011, p. 115).

O que o projeto previu, no primeiro momento, foi servir como uma base de sustentação para futuras demandas na escola. Tendo em vista que planejar e avaliar tem significados distintos, dependendo da ótica que são conduzidos, a perspectiva foi a de construir um ambiente capaz de entender a carência dos alunos e comunidade sem deixar ser influenciado por um comodismo que acaba justificando a situação no discurso de que a conjuntura é essa mesma. Discurso, como: "esta é uma comunidade carente, portanto cheia de problemas e não vai mudar facilmente...".

O que se pensou com a proposta do projeto, na verdade, foi preparar um aluno capaz de pensar sobre si e sobre o outro. Capaz de lutar pelos seus objetivos sem ter medo e fazer justificativas que não condizem com um cidadão pensante. Obviamente, sabese que uma intervenção superficial como esta, é insuficiente para grandes avanços, mas a contribuição do trabalho possivelmente, servirá como fomento para novas projeções, ajustes onde houver a superficialidade. Visou dar um primeiro passo para instigar uma próxima etapa que poderia ter amplitude maior, caso o resultado tivesse caráter satisfatório. Portanto, a reflexão teórica foi ampliada com outros referenciais teóricos que virão em sequência.

Em Subcidadania Brasileira (2018), ao apresentar Taylor e seus argumentos sobre as democracias modernas, Jessé Souza disse: "Taylor, inclusive considera que as democracias modernas deveriam ser avaliadas a partir da forma como elas tratam as minorias..." (SOUZA, 2018, p. 109). Poderíamos nos perguntar: Como a escola tem avaliado o caso? Será que o conceito de minoria apregoado pela escola está dentro 
dos mesmos princípios? Com que olhar a instituição escolar está trabalhando essa dimensão na sociedade?

O autor Souza faz um grande esforço para canalizar essa reflexão para o conceito de dignidade. Ele se preocupa com "....as diferenças sociais tornadas naturais e legítimas, sob o véu mascarador da pretensa igualdade e universalidade que habita a noção de dignidade..." (SOUZA, 2018, p. 110). São situações que merecem maiores reflexões e que a educação como instituição precisa estar atenta, caso contrário, essa mesma instituição pode estar legitimando aquilo que é uma farsa, ou, como disse o autor, servindo como um recurso "mascador" do conceito de dignidade.

A Orientação Educacional como desenvolvimento de relações interpessoais define-se como uma ação no sentido de mobilizar os agentes educativos de forma que cada um, dentro de suas limitações, possa desenvolver relações significativas, com o objetivo de criar um clima educativo que favoreça o processo de aprendizagem-maturação. (LOFFREDI, 1976, p. 25).

Ao assumirmos essa responsabilidade na escola com a função da Orientação Educacional, logo no início do trabalho constatamos que havia muitos desafios a serem sanados e não poderíamos deixar de fazer um diagnóstico preciso destes desafios mais comuns no novo contexto da experiência. Para mobilizar os agentes educativos, como diz a autora Loffredi (1976), a primeira iniciativa foi fazer um levantamento para conhecer melhor a realidade, pensou-se, a partir do diagnóstico, que, poderia se chegar a uma ação concreta na mesma realidade.

Chamou-nos a atenção um artigo voltado ao tema Gestão Escolar enfatizando os processos e as dificuldades do gestor. Nos seus argumentos, o autor falou com bastante propriedade sobre a forma de se fazer uma gestão. Por essa razão, logo na introdução do artigo foi possível perceber que ele pontuou informações a instigar o leitor refletir sobre o que estamos preocupados em mostrar aqui. Entretanto, foi com esta perspectiva que resolvemos destacar a fala do autor, onde se diz, que:

A gestão não é uma mera forma de controle coercitivo na administração, uma mecanização autoritária de controle, todo gestor é parte integrante de um corpo, uma equipe, que busca nas ciências sociais os métodos 
para uma gestão que atente para o lado humano de seu trabalho e das pessoas que fazem parte deste meio. (DIAS, 2019).

A nosso entender, a reflexão do autor foi pertinente, pois a administração é de extrema importância e, portanto, necessária, mas nem todo gestor age com o olhar igual ao proferido pelo autor do artigo. O momento instiga-nos a pensar se queremos um ser humano como pessoa, ser esse, que tem sentimentos, emoções e mesmo na sua criatividade está sujeito a passar por transtornos. Ou, ao contrário disso, será que queremos uma mercadoria a ser usada e descartada quando convir, como mostra o ponto de vista de muitos autoritários aos seus subordinados? Esta última versão parece estar ficando comum na era do mundo globalizado, pois se fala muito em seres humanos como mercadoria.

Prosseguindo a reflexão, outra situação que fez bastante sentido e por essa razão a pontuamos no trabalho. Trata-se do cuidado com a parte organizacional, com vista a criar, ou possibilitar a responsabilidade e respeito entre os envolvidos no ambiente de trabalho. Estamos falando da promoção profissional, pessoal e social dos envolvidos nesse ambiente. Este "clima" de que fala o autor, deve ser o primeiro passo para uma expansão maior. Em nosso caso específico, a preocupação com aluno. A ausência de um ambiente coordenado, organizado, bem gerido, ao contrário do que estamos falando, sinaliza o fracasso, ou uma rotina desgastante no dia a dia.

Todo o trabalho de gestão deve estar em favor da criação de um clima organizacional que vise auxiliar todo relacionamento profissional e interpessoal, construindo uma convivência responsável e solidária. Deverá ser valorizada e apoiada iniciativas que possam promover o desenvolvimento profissional, pessoal e social, além de otimizar o uso dos lugares coletivos disponíveis na escola e do tempo. (DIAS, 2019).

Acredita-se que o futuro conta com os jovens que estejam em ascensão e o autor Goleman (2013) confirma isso sinalizando-os como a parte central da evolução. Inevitavelmente, ao contrário da afirmação, o despreparo desses jovens, pode significar o fracasso da futura geração. Talvez tenhamos que perceber as alertas dadas por pessoas como Goleman (2013), quando, ao falar dos adolescentes americanos "conectados" às máquinas e ao mesmo tempo, "desconectados" das pessoas de uma maneira jamais vista, assusta. Evidentemente, trata-se da parte mais 
preocupante nesta nova era, uma preocupação que é vista até por leigos, mas inevitavelmente, poucas iniciativas no sentido de reverter o caso, estão sendo feitas.

Como o intuito do artigo é discutir o problema local e analisar com maior consciência aquilo que compete a nós e ao nosso compromisso focal, vamos nos deter no raciocínio proposto. Isto não quer dizer que se deve fechar os olhos para os problemas nacional e o global. Tudo está interligado e as consequências de um deixam reflexos no outro. A criatividade humana, cria, e recria situações que coloca todos frente aos desafios que estamos apontando aqui. Resta-nos entender e usar a capacidade inventiva que a humanidade tem para sobreviver da melhor maneira ao bombardeio de informações dos últimos tempos, sem perder o foco.

Ainda, em Goleman (2013), o leitor se depara com diversas informações que são pertinentes. É preciso estar atento a essa realidade! Veja o que ele diz: "As crianças de hoje estão crescendo numa nova realidade, na qual estão conectados mais a máquinas e menos a pessoas de uma maneira que jamais aconteceu antes na história [...]" (GOLEMAN, 2013, p. 30). Esta situação preocupa a muitos e convida o leitor a se atentar para o tamanho dos desafios que a sociedade brasileira enfrenta. Em uma realidade onde há muitas indiferenças, o fracasso é mais evidente ainda, obviamente.

Os adolescentes, a vanguarda do nosso futuro, são o epicentro. No começo desta década, a contagem de mensagens de texto mensais disparou para 3.417, o dobro do número de apenas poucos anos atrás. Enquanto isso, o tempo que passam ao telefone caiu. $\mathrm{O}$ adolescente médio americano recebe e envia mais de cem mensagens de texto por dia, cerca de dez a cada hora acordado. Já vi um garoto escrevendo uma mensagem enquanto andava de bicicleta. (GOLEMAN, 2013, p. 30).

Por mais que a escola demonstre esforço para superar os índices que são baixos, há que se considerar situações da realidade na comunidade em que ela está localizada que influenciam direta, ou indiretamente na aprendizagem do aluno. Visto que a área de abrangência da escola Fernando de Azevedo é uma localidade carente, consequentemente, se entende que essa mesma carência está presente nas famílias, bem como, os transtornos. O que resta, no entanto, é compreender quais são eles e como lidar com tais situações para superá-los. Daí a importância do diagnóstico. 
O autor Goleman (2013), alerta para situações que, segundo ele é simples. No entanto, em uma comunidade onde a maioria é leiga, esta simplicidade, continua complexa. Não parece fácil distinguir a situação sem que haja uma orientação extraídas de leitura dos referenciais pertinentes ao assunto, ou pelo menos, uma informação verbalizada repassada por um trabalho como esse que realizamos. Por essa razão, o cuidado que se teve ao fazer o diagnóstico da realidade em que está inserida a Escola Fernando de Azevedo.

Há dois tipos principais de distrações: sensorial e emocional. Os distratores sensoriais são simples: enquanto lê estas palavras, você está abstraindo as margens em branco ao redor deste texto. Outro exemplo: perceba por um instante a sensação da sua língua no céu da boca este é apenas um em meio a uma interminável onda de estímulos que seu cérebro elimina do contínuo fluxo de sons, formas e cores de fundo, sabores, cheiros, sensações e assim por diante. (GOLEMAN, 2013, p. 37).

Segundo o autor, precisa-se aprender a lidar com a mente, aprender a lidar com os fatos que ocorrem no comportamento neural do aluno, bem como, nos fatos que envolvem as pessoas que estão no contexto escolar. Trata-se de mentes complexas e, na mesma ótica, a situação de muitas das famílias neste local exigem dos profissionais uma dimensão maior de conhecimento para contornar eventuais transtornos, muito esforço no estudo de caso. Cada indivíduo traz consigo uma especificidade que as vezes pode ser equiparada ao outro, mas também pode diferirse, e, no ambiente educacional essa complexidade é muito comum.

Não poderíamos deixar de pontuar outro fator que foi bem elaborado pelo autor, tratase do foco. Esse, talvez seja o grande desafio que a escola precisa se atentar, pois vivemos a era das informações no mundo globalizado que também é a era das distorções que inibe, sobrepõe e/ou impulsiona o desvio do contexto, o foco. Essa é uma das "teclas" a ser acionadas para se alcançar maiores conquistas no aprendizado dos alunos. Apesar de tantas informações, em muitos dos casos, ocorre muito mais a inibição das emoções. Na verdade, ao contrário disso, a humanidade deveria ser a mais bem preparada, emocionalmente e ideologicamente, pela própria criatividade que possui. 
Como o foco exige que abstraiamos as distrações emocionais, nossa estrutura neural para a atenção seletiva inclui a inibição da emoção. Isso significa que quem tem melhor foco é relativamente imune a turbulências emocionais, tem mais capacidade de se manter calmo durante crises e de se manter no prumo apesar das agitações emocionais da vida. (GOLEMAN, 2013, p. 38).

Visto que as gerações de professores ainda são frutos de uma realidade distinta da atual na sua formação superior, ou, pelo menos, na base estrutural da sua formação. Os desafios parecem inevitáveis, são estes guerreiros, os responsáveis pela transição no contexto de sociedade até à atual, como mostra a expressão: "São, na verdade, heróis aqueles que, vindos da sociedade tradicional, tiveram a coragem de arriscarse à aventura dessa era nova." (LOBO, 2010, p 82). Ao refletir com maior precisão, você irá compreender o que estamos desvendando aqui.

Não basta uma formação acadêmica, é preciso atualização constante para que se possa acompanhar as mudanças no decorrer dos tempos. Entretanto, há de se reconhecer que tais mudanças acontecem de forma muito mais acentuadas nos últimos tempos, exigindo do profissional adequações constantes. Por essa razão, afirmamos com bastante convicção de que faz um imenso sentido um trabalho com a formação continuada dos professores, atualizando-os ao contexto da realidade. $O$ momento mostra que é preciso se reinventar!

A formação continuada de professores é um dos suportes para a atualização e é, por essa razão, que surge a reflexão a seguir: "Constata-se que há no país uma má articulação entre profissionalidade e profissionalização, reflexo de uma baixa integração do tripé universidades-centros formadores/redes de ensino/escolas". (ABRUCIO, 2016, p. 34). Talvez o país deva se atentar para o que diz o autor. $\mathrm{O}$ mundo "evolui", as mudanças são uma constante e a educação não consegue digerir essas constantes transformações que, ora transforma, ora deforma e causa diversas circunstâncias sociais.

[...]. Pensar profundamente exige manter a mente focada. Quanto mais distraídos estamos, mais superficiais são as nossas reflexões. Da mesma forma, quanto mais curtas as nossas reflexões, mais triviais elas 
tendem a ser. Caso estivesse vivo hoje, Heidegger ficaria horrorizado se Ihe pedissem para tuitar. (GOLEMAN, 2013, p. 40).

A reflexão apresentada por Goleman parece bastante pertinente e sinaliza a causa de diversas dificuldades enfrentadas na real situação na sociedade atual, principalmente na comunidade em que estamos desenvolvendo o trabalho. O foco, neste caso, é a carência, muito comum, no autocontrole dos alunos da escola pesquisada. E, como mostra o autor, "mentes focadas podem muito mais", isso significa um indicativo pertinente ao que se deve ater ao trabalho nesta escola, cabe aos profissionais da Instituição pesquisada, pensar como estimular a mente dos alunos à concentração.

Ao pensar o social, temos a convicção de que o foco, ou a ausência dele, é o maior responsável pelo contexto de sociedade em que o país vive e isso, provavelmente, não difere do âmbito global. Porém tratar desse assunto de forma ampla exige do pesquisador maior análise. Focaremos ao problema local, mesmo consciente de que um problema local é o reflexo de um problema maior, nacional, que por sua vez sofre as consequências de outro, o global. A conjuntura da era moderna está sujeita ao capital - econômico - que controla o político e o social com as suas instituições subordinadas, mas assunto serve para outro momento!

Voltemos a refletir o local, onde o autor Goleman (2013), preocupa mostrar a situação dramática que a humanidade tem enfrentado nos últimos anos. O nível de tensão da sociedade moderna é, simplesmente, estarrecedor. Diz o autor: "a atenção entorpece o controle mental', como você verá na citação abaixo. Visto que o cérebro humano é a peça chave da estrutura intelectual, resta-nos estar atentos às pressões impostas aos alunos pelo mundo globalizado e, portanto, é dever ajudá-los na conduta ativa da sua cognição.

Sobrecarregar a atenção entorpece o controle mental. É nos momentos em que nos sentimos mais estressados que nos esquecemos de nomes de pessoas que conhecemos bem, sem falar em seus aniversários, aniversários de casamento e outras informações socialmente cruciais. (GOLEMAN, 2013, p. 52).

Felizmente há pessoas preocupadas em diagnosticar os problemas mais comuns que são causadores do estresse, as impulsividades das pessoas. É evidente que as 
causas são diversas, mas uma em especial é destacada, segundo informações do autor, trata-se da obesidade nos Estados Unidos. A era digital empolga, mas ao mesmo tempo assusta devido aos supostos efeitos que sobrecarregam as mentes humanas. Há que pensar alternativas para que o próprio cognitivo, descubra, através da sua capacidade, alternativas, que modere os desajustes. A mesma situação deve estar se espalhando por outros países e Continentes.

Mais um exemplo: obesidade. Pesquisadores descobriram que a prevalência da obesidade nos Estados Unidos ao longo dos últimos trinta anos acompanha a explosão dos computadores e dos equipamentos tecnológicos na vida das pessoas - e suspeitam que não seja uma relação acidental. A vida imersa em distrações digitais cria uma quase constante sobrecarga cognitiva. E essa sobrecarga mina o autocontrole. (GOLEMAN, 2013, p. 52).

Temos que concordar com as orientações de Goleman, porém acrescentamos outros fatores como possíveis colaboradores no mal do século a serem sanados. Trata-se da depressão que é causadora de transtornos, dentre outros, é influenciada pela má qualidade na alimentação, além, é claro, da desordem imposta às pessoas na formação cultural, política-ideológica e até mesmo, religiosa. Na verdade, a liberdade tão bem reivindicada pelos lluministas, complementada pela Revolução Francesa de 1789, atualmente, ganhou outra dimensão, a da não racionalidade, ou irracionalidade, como queiram entender, assunto bastante polêmico.

Borges (2017, p. 29) em Raízes da Depressão fala na Cauterização da Consciência. Para o autor: "Ao invés de corrigir o que está errado, simplesmente chamamos o errado de certo. Essa tem sido uma das principais marcas dessa geração: a inversão de valores...". Isso ficou evidente com a citação. Esta inversão de valores apontada pelo autor pode ser uma das causas que provocam a irracionalidade. É na ausência de valores, filosoficamente falando, que aparece a desrazão, ou não-racionalidade. Ou, ainda, em (BORGES, 2017, p. 31): "...A lei do menor esforço e do menor prazer...". Uma das formas, segundo ele, de suprimir o mau humor.

Sobre a questão nutricional (BORGES, 2017, p. 13) fala na importância dos neurotransmissores e diz que: "Os níveis cerebrais de serotonina são dependentes da 
ingestão de alimentos fonte do aminoácido triptofânio e de carboidratos. ...". E, em se tratando da deficiência dos minerais: "cromo, magnésio e zinco", o autor aponta: "...quatro grandes problemas de saúde: em primeiro lugar, a depressão, seguida das alergias, dores (principalmente as lombares) e os distúrbios gástricos." (BORGES, 2017, p. 22). Na informação anterior a preocupação estava na distorção ideológica e, neste último caso, a ausência nutricional, o caminho para a depressão.

Quanto à formação cultural e a visão político-ideológico de Jessé Souza com suas reflexões a partir dos estudos com a sociologia, ele questiona em "Subcidadania Brasileira (2018)", a separação entre seres de primeira e segunda classe. Veja que o autor fala na sua luta desde a juventude, por “...desconstruir a falsa teoria hegemônica sobre o Brasil, que "tira onda" de crítica social, baseada do que chamaria mais tarde de "corrupção dos tolos" ..." (SOUZA, 2018, p. 9). Não é possível pensar a atualidade sem navegar pelas distintas dimensões que estamos apontando aqui.

Atualmente, a vida parece regida pelo impulso num grau preocupante. Uma inundação de anúncios publicitários nos estimula, de baixo para cima, a desejarmos uma infinidade de bens e a gastarmos hoje sem pensar em como pagaremos amanhã. Para muitos, o reino do impulso vai além dos gastos e empréstimos excessivos, chega ao ponto do comer excessivo ou de outros hábitos característicos de adições como entupir-se de doces ou passar horas intermináveis olhando fixamente para algum tipo de tela digital. (GOLEMAN, 2013, p 54).

Sobre a questão cultural, pode-se utilizar, ainda, referências em (COTRIM, 2002, p. 224), apontando "a morte da razão crítica” em Horkherimer e Adorno. Trata-se da "eficácia" dos veículos de comunicação que massificam toda uma situação capaz de destroçar a mentalidade de uma geração. São séculos de bombardeio. Ambos os autores nos possibilitam entender o tema. Mas, voltando em Souza (2018), quando ele comenta a visão de Taylor em "Subcidadania Brasileira", e fala na hierarquia moral, o sociólogo demonstra que: “...a violência pré-política dos excluídos apenas legitima o uso da violência institucionalizada...". (SOUZA, 2018, p. 45).

Mais um detalhe interessante: “...Se a lei formal prega a igualdade de todos, são esses os mecanismos invisíveis que produzem e justificam a desigualdade permanente ao arrepio da regra jurídica”. (SOUZA, 2018, p. 45). Veja aqui a dramaticidade do que 
estamos falando. Como entender a moral em um cenário tão conturbado desse. Se, de um lado, é óbvio que a humanidade está agindo desconfortavelmente, do outro, é preocupante perceber a ação fruto do próprio desmando causado pela pressão imposta à sociedade, seja ela cultural, ou político-ideológica.

Não se pode ser ingênuo a ponto de condenar somente o indivíduo em sua ação, no caso específico, o aluno em sua astúcia, pois estamos falando em uma vítima do desmando político, ideológico, cultural e até institucional, caso a educação em sua prática de ensino não o compreenda. Ao se posicionar do lado do desprovido aluno em busca de jogar para fora suas angústias, angústias estas, fruto da ação da própria sociedade imposta à família, percebe-se que esta mesma família se desestrutura por não entender a imposição da sociedade e, automaticamente, acaba transferindo suas angústias aos filhos, dando claras evidência do verdadeiro culpado.

Talvez entendamos melhor o que estamos pontuando aqui ao percebermos o que mostrou Daniel Goleman em "Mentiras essenciais, verdades simples" quando falou na psicologia da autoilusão. Para o autor “...somos o que somos, aprendemos o que sabemos em virtude dos esquemas que adquirimos no percurso. Os esquemas se acumulam com o tempo; os esquemas que temos num dado ponto são o produto final de nossa história pessoal e particular". (GOLEMAN, 1997, p. 78). Esquemas para ele nada mais é do que as regras que, inteligentemente, nos servem de guia mental. Essa mescla de situações põe o indivíduo adulto em contrastes consigo mesmo, muito mais complexo se torna para uma criança que é mal formada desde suas origens.

Por essas e outras razões, como formação incompatível em relação à evolução dos últimos tempos, enfrentamos diversos problemas emocionais com profissionais que se sentem culpados por não darem respostas à sociedade, dentro do esperado. $\mathrm{Na}$ verdade boa parcela desses profissionais não estão cientes das mazelas de cunho ideológico que estão sucateando a mente das pessoas e querem a todo o custo solucionar aquilo que é irreversível, ser conduzido, sem entender essa ótica de raciocínio. Estamos vivendo um tempo em que a liberdade aprisiona a mente e coloca o indivíduo num cativeiro insustentável, a ponto de, nos casos extremos, chegar ao suicídio. Vários casos já ocorreram nesse sentido e passam despercebidos. 
A sociedade cobra a eficiência dos profissionais e tem a sua razão, porém não há uma explicação clara para solucionar o problema nesse momento da história, a formação dos profissionais ainda é ineficiente para a superação do desafio atual e quando há o embate entre o aluno "rebelde", a família que muitas vezes se faz ausente e o professor sem alternativas viáveis, tudo isso vira um caos e este drama, ideologicamente falando, neutraliza a todos. Daí um conflito interno negativo que minimiza o sujeito a ponto de convencê-lo de que ele é quase um lixo, seja ele o professor, ou o aluno. A invisibilidade do sistema é traduzida na eficácia, ou não, do professor, na aceitação da família de que seu filho é um fracassado, justificando, de forma cruel o fracasso de ambos.

\section{AS AÇÕES DESENVOLVIDAS}

O levantamento dos dados para identificação dos alunos a serem atendidos, a princípio, se deram a partir das informações que havia na ficha individual dos alunos na sala da Orientação. No diagnóstico inicial, usou-se as fichas individuais e os registros de ocorrências dos alunos identificando nomes recorrentes na sala da Orientação. Depois, foi feito um levantamento mapeando possíveis nomes a serem indicados ao diálogo, contando com a ajuda dos professores. E, a primeira grande surpresa que se teve ao iniciar o convite a esses alunos mapeados, logo nos primeiros esclarecimentos sobre a proposta do projeto, foi o nível de aceitação dos convidados.

De forma inusitada, nenhum dos convidados tiveram qualquer tipo de rejeição instantâneo, se esperava o oposto disso. Neste sentido, foram realizados levantamentos e os convites individualizados no intuito do esclarecimento base de algumas situações, como, por exemplo: o que se propunha fazer..., o compromisso que o aluno passaria a assumir a partir do momento em que decidisse participar do projeto, dentre outros. Surpreendentemente, todos, sem exceção, aceitaram o desafio, alguns até ficaram ansiosos para chegar o dia do primeiro encontro!

Quanto ao primeiro encontro, foi planejado uma conversa de uma hora e meia - (1:30), tempo igual para os dois períodos. O trabalho dialógico no coletivo começou no dia 07/08/2019 com os alunos do Período Matutino das 8:00 horas às 9:30 horas e seguiu- 
se, também, no dia 08/08/2019 das $14: 00$ horas às $15: 30$ usando os mesmos mecanismos metodológicos utilizados para o período matutino, com o período vespertino. Quanto à programação, além de ser mais claro nas informações e objetivo como a intenção do projeto, esclareceu-se algumas dúvidas falando na importância de se entender a funcionalidade do cérebro, bem como a psicologia. Falou-se no QI e no QE[2], acrescentou no diálogo contribuições advindas da Sociologia envolvendo os interesses e os entraves sociais, mas também, informações da Filosofia com enfoque em Moral e Ética. Nada de especial na conversa, simplesmente o carinho e a atenção nas expectativas.

É importante informar que, no intuito de preservar as crianças, evitou-se destacar nomes, neste caso, de forma sequenciada e numericamente, mas aleatória, no sentido alfabético, classificou-se o grupo a partir da letra $A 1, A 2, A 3 \ldots$ e, assim, sucessivamente, até chegar ao A 20 que foi o último aluno. Entendeu-se que a forma mais adequada para preservar os alunos seria o uso do codinome apontado. Rapidamente eles se acostumaram com a situação e isso facilitou no diálogo, no registro de informações pessoais. Também, ajudou na preservação do sujeito quando havia uma opinião de cunho crítico.

Dentre os temas trabalhados nos doze encontros, além dos temas já citados, aparecem: diálogo sobre atitudes que ocorrem a partir da ação inconsciente que podem chegar a atos agressivos (impulso), ação agressiva por insegurança, alguns exercícios proporcionando o uso da audição com movimentos ao redor do ambiente e a oportunidade em comentar suas percepções. Também se falou no funcionamento do corpo administrativo da sociedade, o pensamento do trabalhador, no pensamento do mundo globalizado, seus interesses e disputas hegemônicas, além de informações e distorções que ocorrem na sociedade.

Outro importante diálogo foi relacionado ao caráter humano, a formação que tem como base a família, a escola e a sociedade envolvendo o tema cultura, trabalho e crença. Falou-se na pressão social dos últimos tempos, no estresse do cotidiano que tem levado pessoas ao suicídio por não aprenderem a autogerir-se. Durante todos os encontros, além de anotações havia as avaliações, hora envolvendo o indivíduo, hora 
o coletivo. Perguntas foram feitas servindo como estímulo ao pensamento e liberdade de expressão. Enfim, é necessário justificar que diversos imprevistos ocorreram no decorrer do processo, como faltas na casa de muitos alunos, semana sem água no bairro, compromissos dos alunos na sala de aula com outras atividades. Mas, considerou-se importantíssimo uma proposta aceita do desafio em fazer uma apresentação teatral para a escola no momento cívico e, na presença de alunos e funcionários. Foi um grande desafio, tendo em vista que se tratava de alunos que sempre estavam ausentes e não apareciam nas apresentações cotidianas.

Como exercício inicial, preparamos uma miniapresentação, sem muita exigência. Entre dificuldades e força de vontade, saiu a primeira apresentação teatral, com o tema: "bullyng", mesclada a ela, uma exposição de um slide apresentado pelo Orientador Educacional, com o mesmo tema. A avaliação da escola foi bastante positiva e esse momento gerou impulso para o novo desafio. Desta vez, um teatro com base na trilogia de Augusto Cury que tem como tema: "O Vendedor de Sonhos". Porém o teatro, foi criado pelo Orientador e apresentado pelos alunos ganhando o título de: "O SUICIDA".

Enfim, depois de muitos desafios e expectativas chegou o final do projeto demonstrando um saldo positivo, pois além de possibilitar diversas reflexões, também ficou claro que é possível muito mais. Ao final da experiência, a redução do número de atendimentos na sala do SOE[3] da escola caiu em mais de $50 \%$. As fichas dos alunos comprovaram as mudanças na redução de ocorrências desde que começou o projeto. É preciso esclarecer que não foi possível atingir diretamente a parte externa à escola (família/comunidade) em função do pouco tempo para desenvolver o projeto. Ao final, os alunos receberam um certificado de participação do projeto (simbólico e elaborado pela Supervisora da escola e pelo Orientador Educacional). Encerramos o projeto envolvendo todos os alunos do $3^{\circ}$ e $4^{\circ}$ anos em uma palestra de intervenção externa e complemento ao nosso trabalho. A representação gráfica e os relatos de dados da pesquisa, bem como, suas análises, aparecerão como anexos no artigo. 


\section{CONSIDERAÇÕES FINAIS}

Não há dúvidas de que o desafio foi grande e dependeu de muita cautela por parte do seu executor. No entanto, há a certeza de que não faltaram esforços para atingir os objetivos propostos. Resta saber como comportará os alunos envolvidos nas análises considerando o trabalho do momento e a sua conduta posterior. Certamente, o êxito em qualquer conquista, dependerá da capacidade flexível do seu executor, bem como, da iniciativa do indivíduo e a sua busca por entender e alcançar os objetivos propostos. Também, por influência do meio em que ele se inserir no decorrer da sua vida.

Viu-se, que no primeiro capítulo do artigo, o esforço foi em pontuar a "Base estrutural do projeto de pesquisa" ao qual gerou o presente artigo. Neste caso, começou por mostrar o tamanho do desafio que a escola enfrentava para sanar os problemas e assim como a escola mencionada, acredita-se que tantas outras devem enfrentar os mesmos desafios. Seguiu-se com a apresentação do título do projeto e o passo a passo dos primeiros ajustes metodológicos para a proposta e as suas ações. Também apareceu a afirmação do compromisso do Orientador em produzir o presente artigo ao final da experiência.

O segundo capítulo do artigo, apresentou os teóricos envolvendo análise, em sua maioria de cunho psicológico que muito tem a ver com o trabalho, mas também não deixou de trazer posturas críticas coma sociologia e a filosofia, contando ainda, com informações voltadas à gestão. Mas também houve o esforço em mostrar experiência relacionadas à Orientação Educacional, caminho pela qual surgiu a proposta do projeto e não poderia deixar de destacá-la nesse momento. Obviamente, sem o apoio da equipe gestora da escola, somados ao apoio dos professores e alunos, nada teria acontecido.

Enfim, no terceiro e último capítulo, apareceram as ações desenvolvidas no decorrer do projeto, complementados pelos anexos e gráficos que complementam a pesquisa. Fica o desejo incontestável de fazer nascer, ou renascer seres humanos criativos, dignos de serem respeitados como humanos e não como meros seres que extrapolam as suas fronteiras sem o sentimento que se deve ter. Pensou-se em um sujeito capaz 
de se sentir gente, e não, um objeto, quase um "lixo" a ser descartado pela história, como acontece em alguns casos na sociedade. Por essa razão, recomenda-se a experiência aos estudantes, professores, gestores e, principalmente orientadores educacionais. Trata-se de um sonho a ser sonhado em qualquer ambiente educativo. Os seres humanos nascem e buscam a felicidade a todo custo, muitos agem de forma inadequada e não as encontra, mas verdadeiramente, há a busca por ela e esse é um direito que todos deve ter!

\section{REFERÊNCIAS}

ABRUCIO, Fernando Luiz. Formação de professores no Brasil: diagnóstico, agenda de políticas e estratégias para a mudança. Moderna. São Paulo, 2016).

BORGES, Marcos de Souza. Raízes da Depressão: Enfrentando o grande mal do século. Jocum. Paraná, 2017.

COTRIM, Gilberto. Fundamentos da Filosofia. Histórias e Grandes Temas. ed. 15. Saraiva. São Paulo, 2002.

DIAS, Renan Italo. Gestão escolar: Os processos e dificuldades do gestor escolar. Revista Científica Multidisciplinar Núcleo do Conhecimento. Ano 04, Ed. 06, Vol. 07, pp.13-20. junho de 2019. ISSN: 2448-0959.

FARIAS, Isabel Maria Sabino de. [et. al.]. Didática e Docência: Aprendendo a profissão. 3. ed., Liber. Brasília, 2011.

GOLEMAN, Daniel. Foco [recurso eletrônico]: a atenção e seu papel fundamental para o sucesso. Tradução: Cássia Zanon. 1ํed. Objetiva. Rio de Janeiro, 2013.

, Daniel. Mentiras Essenciais Verdades Simples: a psicologia da autoilusão. Recco. Rio de Janeiro,1997.

LOBO, Yoanda. Cecília Meireles. Coleção Educadores MEC. Massangana. Recife, 2010. 
LOFFREDI, Laís Esteves. Paradigma de orientação educacional: baseado no modelo de relação-de-ajuda de Carkhuff. F. Alves. Rio de Janeiro, 1976.

SOUZA, Jessé. Sucidadania brasileira: para entender o país além do jeitinho brasileiro. Leya. Rio de Janeiro, 2018.

\section{ANEXOS}

\section{INFORMAÇÕES E GRÁFICOS}

O primeiro gráfico mostra a tentativa de entender o que pensa o aluno, o sentimento em relação à família, e ainda, visa identificar situações relacionadas ao local de moradia. Considera-se na avaliação as respostas de todos os alunos selecionados e o trabalho de motivação, antes mesmo da palestra como intervenção externa, apresentado pelo professor André. Neste primeiro caso, as opiniões representadas nos gráficos, são dos alunos envolvidos no projeto. Extraiu-se no primeiro gráfico três curiosidades: primeiro aparece a demonstração de que uma maioria dos alunos se consideram felizes, contradizendo a revelação na prática por determinadas rebeldias, a angústia e o estresse de muitos alunos; a segunda curiosidade é em relação ao local de moradia garantindo a ideia de uma organização tanto na rua com asfalto, quanto na rua sem asfalto, acrescido de um índice que aponta a rua como suja e desorganizada; e por último e terceira curiosidade está na preferência pelos país, obviamente, como era esperado, a mãe está em destaque, como se pode ver no gráfico I. 


\section{Gráfico I}

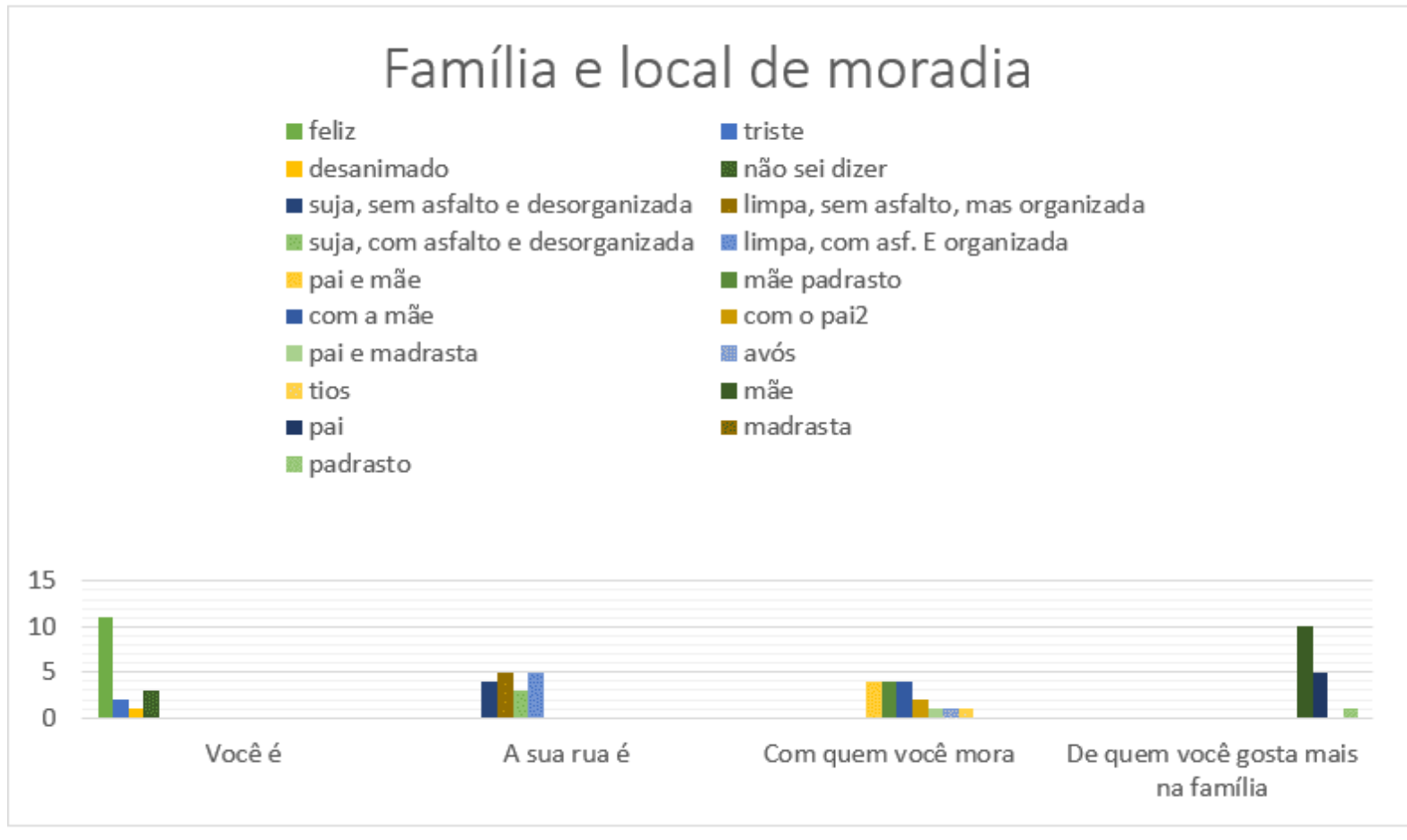

(Fonte própria)

O segundo gráfico visou identificar a relação família/escola. Na ordem crescente, viuse que os alunos apontam que são felizes na família, acrescido de dúvidas. Também mostrou que as famílias acompanham os trabalhos da escola, mas ajudam pouco em casa, o índice de famílias que não participa da vida do aluno, é algo pertinente a ser observado. Há um número maior de alunos que gostam da escola, porém o índice de alunos que não gostam de estudar é considerável, assim como, a motivação em vir para a escola varia entre vir para estudar e ser obrigado a vir. 
Gráfico II

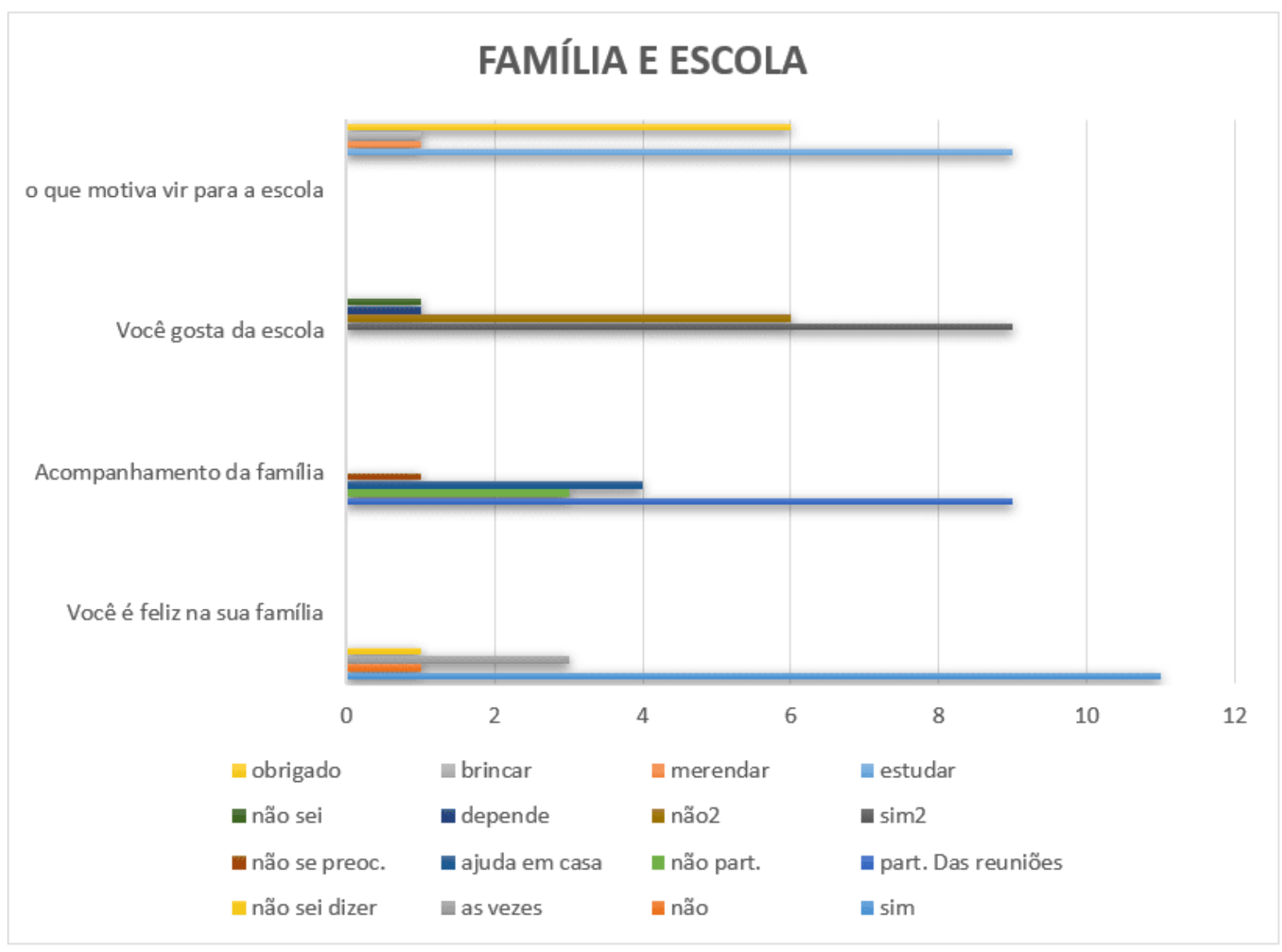

(Fonte própria)

O terceiro gráfico procurou avaliar o desempenho dos alunos, neste caso, viu-se que a maioria se considera inteligente, apesar de haver muitos alunos se considerando fracassado. Para a resposta sobre o que motiva a conduta do aluno, viu-se que uma maioria não soube responder, no entanto, sinalizam a sociedade como a maior responsável. Quanto a origem da tristeza, os alunos nivelaram a opinião entre a dúvida e a certeza pondo em xeque a família e a sociedade como responsável por essa influência, o certo é que os alunos afirmam estar chateados. 
Gráfico III

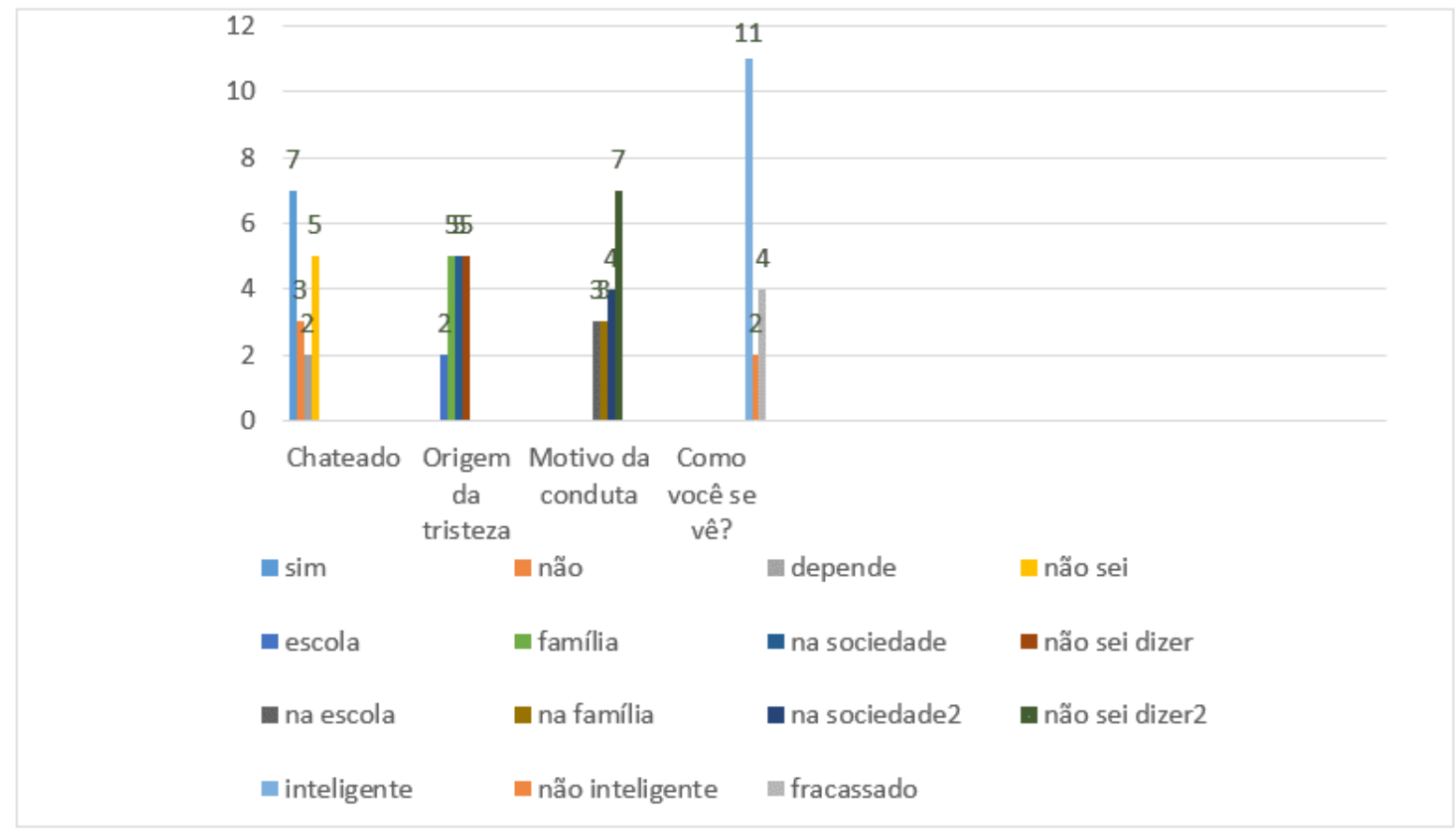

(Fonte própria)

O quarto gráfico visou adentrar no cotidiano do aluno e investigar o contato com o mundo dos vícios (bebida, droga ou outro), viu-se que a maioria conhece alguém com um desses vícios. Ao ser interrogado sobre o que o aluno não quer ser quando crescer, houve muita indecisão e a maioria não soube responder, a certeza maior foi a de que não querem as drogas. Em relação ao compromisso com o projeto, ficou evidente o interesse da maioria, e por fim, os a maioria sinalizou o interesse por um certificado de reconhecimento pela mudança de conduta a partir do projeto a ser providenciado pela escola e entregue em ato público perante os demais colegas da escola. 
Gráfico IV

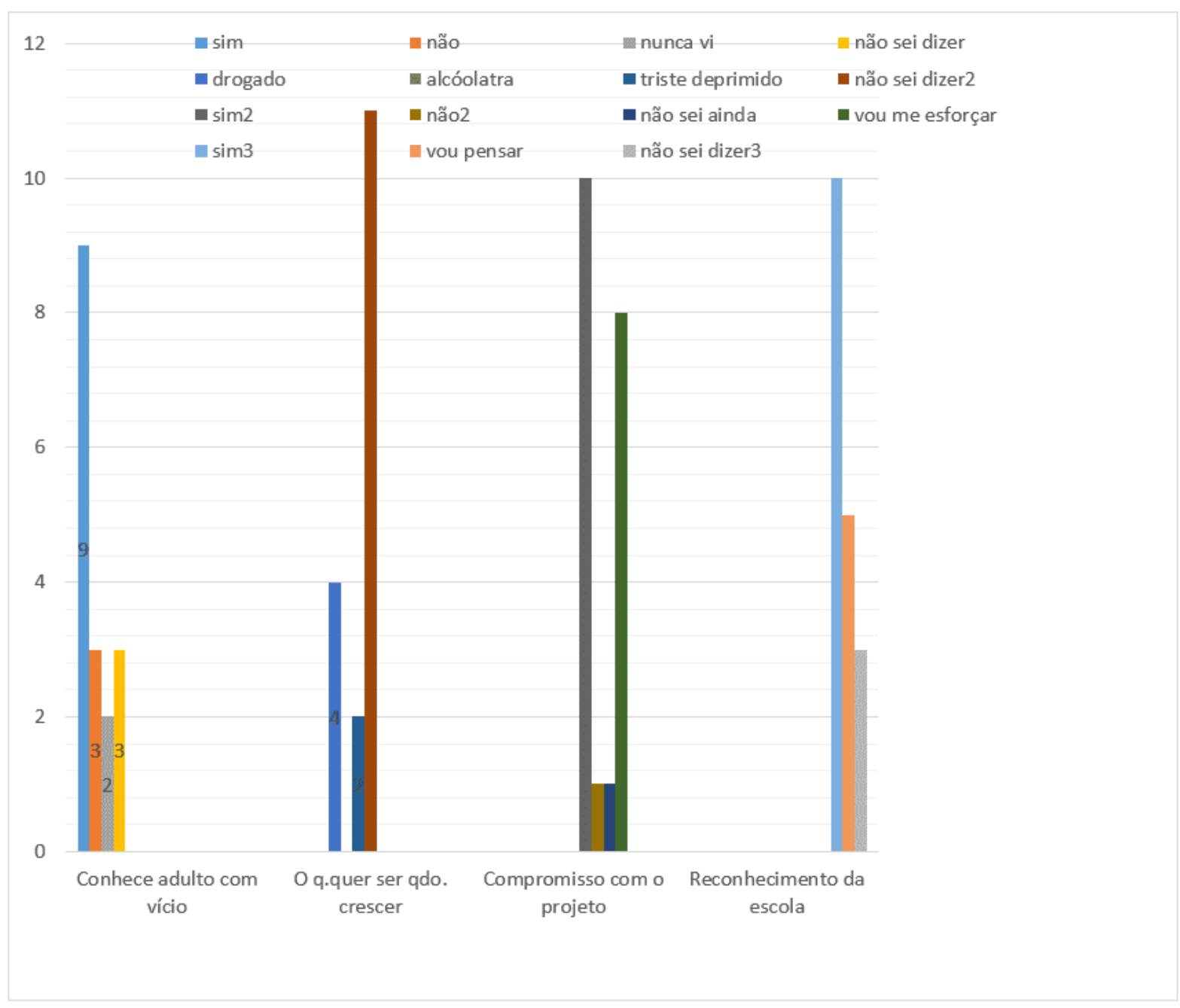

(Fonte própria)

$\mathrm{Na}$ avaliação sobre a evolução diária do aluno em sua individualidade, bem como, o nível de desempenho em diálogos coletivos feitos no decorrer do projeto. Observouse nos dois gráficos, evolução positiva, apesar de uma forte situação parcial. Chamou a atenção outra observação importante no quinto gráfico, foi o número de faltas elevados nas reuniões devido à ausência de alguns alunos da escola, dentre eles, um aluno que quase não participou das atividades e no quarto bimestre pediu a transferência da escola antes do término do projeto. O sexto gráfico mostrou que a evolução do grupo esteve entre muito bom e bom, destacando o grande número de faltas. Enfim, viu-se com base no diagnóstico que é possível ampliar a reflexão em 
outros momentos, expandir as reflexões e envolvimento a família e a comunidade. Estas são as ponderações do trabalho, um trabalho extraclasse, feito com muito carinho.

\section{Gráfico V}

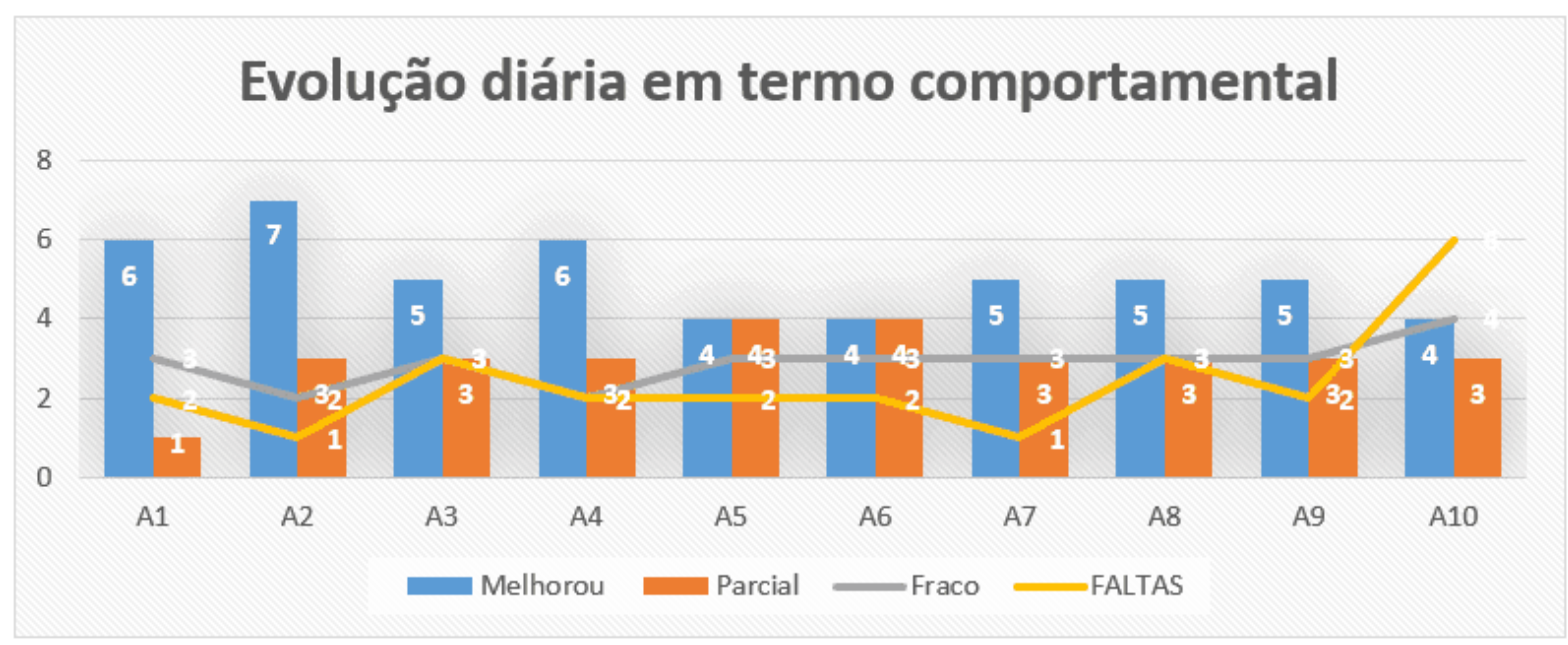

(Fonte própria)

Gráfico VI

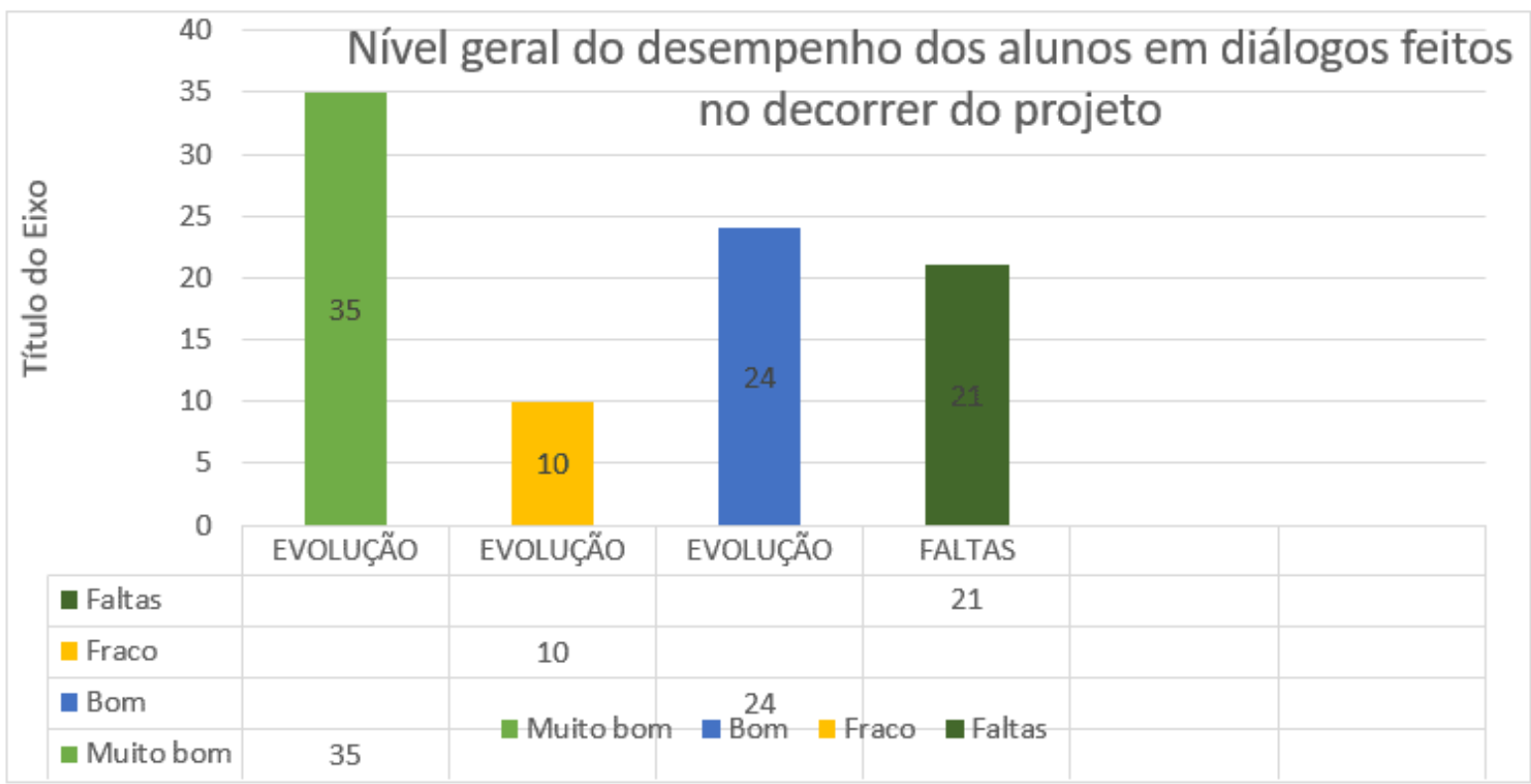

(Fonte própria) 


\section{INTERVENÇÃO EXTERNA - PALESTRA COM O PROFESSOR ANDRÉ L. O. RODRIGUES}

Ao final do projeto buscou-se trabalhar uma palestra, uma proposição de cunho motivacional a complementar as reflexões: para a intervenção externa convidou-se um professor da região que está se especializando na área da psicologia e possui experiência com palestras, ficando na sua responsabilidade adequar uma palestra para todos os alunos da escola dos $3^{\circ}$ e $4^{\circ}$ anos. Segue abaixo uma síntese, biografia do palestrante.

André Oliveira é palestrante, professor, graduado em pedagogia, com especialização em psicopedagogia. Possui experiência de 16 anos em educação do campo e Pedagogia da Alternância. É doutorando em Psicologia pela UCES - Universidade Ciências Empresariais e Sociais de Buenos Aires. É mentor e criador da Empresa Amora Business que atua no desenvolvimento de pessoas e organizações com foco em relacionamento e liderança. É psicoterapeuta e facilitador de mudanças com a metodologia da Clean Language e através da hipnoterapia. Nos últimos cinco anos têm impactado mais de três mil (3.000) pessoas em Rondônia e, seus trabalhos, especialmente no campo da Inteligência Emocional, têm ganhado destaque em diversas organizações. Biografia apresentada pelo palestrante.

Segue avaliação do trabalho com a intervenção externa feita pelo professor André. $\mathrm{Na}$ demonstração gráfica viu-se que todas as séries avaliaram positivamente, tanto os alunos do período matutino, quanto os alunos do período vespertino, como mostram os gráficos sétimo e oitavo relacionados à palestra. O nono gráfico está relacionado ao percentual (média) de aceitação dos alunos da palestra nos dois períodos. Ao final da organização gráfica surge, a avaliação dos professores que participaram da mesma palestra com o professor André e o décimo gráfico. 
Gráfico VII

\section{MATUTINO. VOCÊ GOSTOU DA PALESTRA?}

으 $\mathrm{A}=3^{\circ} \mathrm{B} \quad 4^{\circ} \mathrm{A} \quad 4^{\circ} \mathrm{B}$
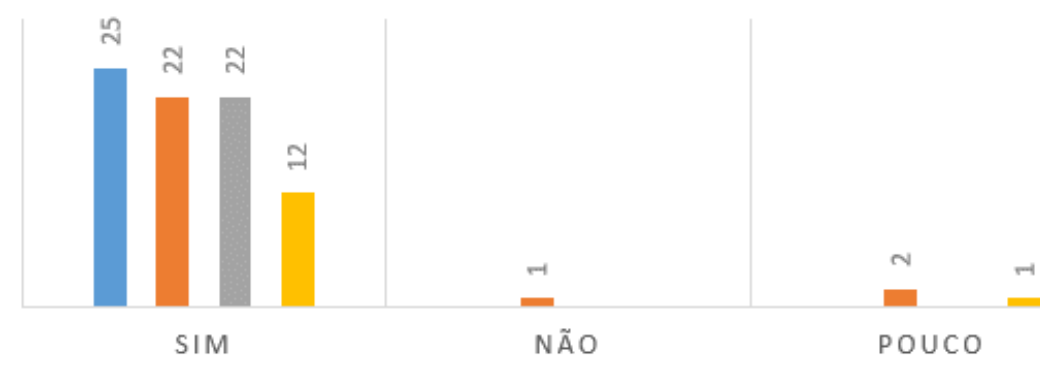

(Fonte própria)

Gráfico VIII

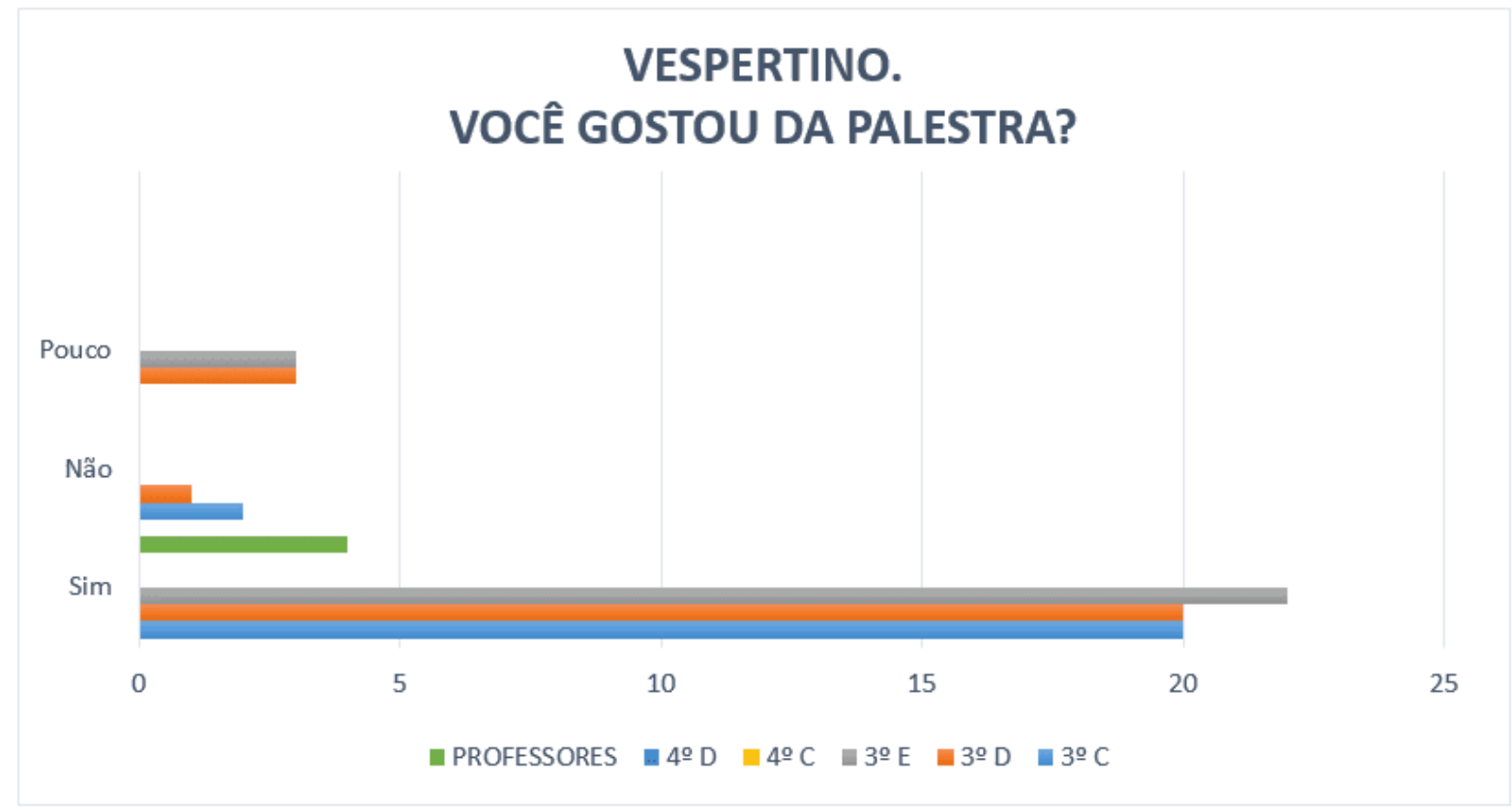

(Fonte própria)

RC: 62875

Disponível em: https://www.nucleodoconhecimento.com.br/educacao/o-dialogo 
Gráfico IX

\section{Avaliação geral dos alunos das turmas}

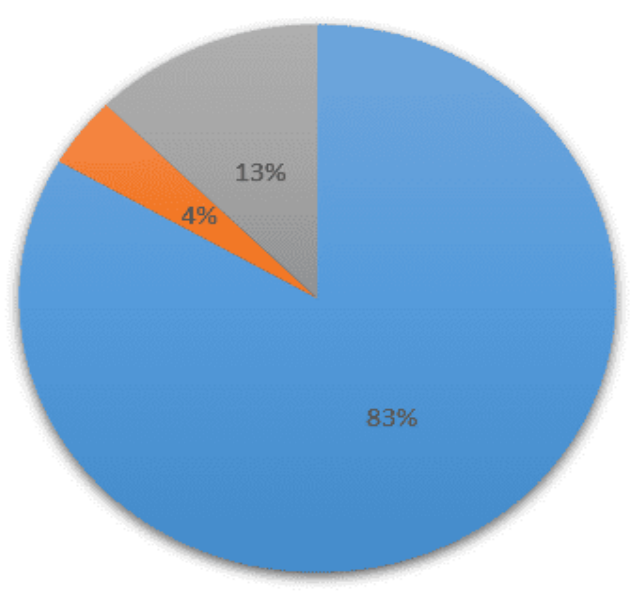

(Fonte própria)

Gráfico X

\section{Avaliação geral dos professores}

(Fonte própria)

RC: 62875

Disponível em: https://www.nucleodoconhecimento.com.br/educacao/o-dialogo 


\section{APÊNDICE - REFERÊNCIAS DE NOTAS DE RODAPÉ}

2. QI - Quociente de inteligência; QE - quociente emocional.

3. SOE - Serviço de Orientação Educacional.

Enviado: Setembro, 2020.

Aprovado: Outubro, 2020. 